\title{
The Role of Historically Black Colleges or Universities in Today's Higher Education Landscape
}

\author{
Linda Knight*, Elizabeth Davenport ${ }^{1}$, Patricia Green- Powell ${ }^{2} *$ \& Adriel A. \\ Hilton $^{3} *$
}

*Ph.D., Graduate Studies and Research, 469 Tucker Hall

Florida A\&M University, Tallahassee, FL 32307, USA

E-mail: linda.knight@famu.edu

${ }^{1}$ *Ph.D., 309-A Gore Educational Center-A, Florida A\&M University

Tallahassee, FL 32307, USA

E-mail: elizabeth.davenport@famu.edu

${ }^{2}$ *Ph.D., 300-A Gore Educational Center-A

Florida A\&M University, Tallahassee, FL 32307, USA

E-mail: patricia.greenpowell@famu.edu

$3 *$ Ph.D., 605 Washington Street

P.O. Box 1857, Fayette, IA 52142, USA

E-mail: hiltona@uiu.edu

Received: April 16, 2012 Accepted: May 23, 2012 Published: June 24, 2012

doi:10.5296/ije.v4i2.1650 URL: http://dx.doi.org/10.5296/ije.v4i2.1650 


\begin{abstract}
Historically Black Colleges and Universities (HBCUs) are effective in graduating African American students who are poised to be competitive in the corporate, research, academic, governmental and military arenas. Specifically, over half of all African American professionals are graduates of HBCUs. Nine of the top ten colleges that graduate the most African Americans who go on to earn PhDs are from HBCUs. More than $50 \%$ of the nation's African American public school teachers and 70\% of African American dentists earned degrees at HBCUs. Finally, both Spelman and Bennett Colleges produce over half of the nation's African American female doctorates in all science fields. This article discusses the importance of HBCUs in today's higher education landscape.
\end{abstract}

Keywords: African American, college, $H B C U$, higher education 


\section{Introduction}

Today, the nation's minority population is steadily rising and now makes up 35 percent of the United States (U.S.) population, illustrating a trend that could make minorities the new American majority by 2050. New Census Bureau data estimates that minorities added more than 2 percent to the U.S. population in 2009 increasing to 107.2 million people, as a result of Hispanic births and more Americans describing themselves as multiracial. During this period, the White population remained flat, making up roughly 199.9 million, or 65 percent, of this country's population. Just ten years ago, Whites comprised 69 percent of the total population and minorities 31 percent. Currently four states - Hawaii, New Mexico, California and Texas - as well as the District of Columbia, have minority populations that exceed 50 percent (Census Bureau, 2010). Thus, such demographic changes in the nation will be reflected in the higher education student population.

The minority shift is taking place at a time when American universities are failing at graduating students---any student. In fact, data recently released by the National Center for Education Statistics (NCES, 2009) show that in 2008, four-year Institutions of Higher Education (IHEs) graduated less than 60 percent of their students in six years. In fact, public colleges and universities are less effective than not-for-profit institutions, which on average do a better job (NCES, 2009).

The problem exists despite an increase in enrollment in U.S. IHEs which have increased by 14 percent between 1987 and 1997 and 26 percent between 1997 and 2007, from 14.5 million to 18.2 million. Most of the growth was in full-time student enrollment, which rose to 34 percent from 1997-2007. During this same period, the number of part-time students rose by 15 percent. In regards to gender, the number of females rose 29 percent, compared to an increase of 22 percent in the number of males during that same period. In addition, enrollment in accredited 2-year colleges, 4-year colleges, and universities also rose during this period (NCES, 2009).

Since 1984, the number of females in graduate schools has exceeded the number of males. Between 1997 and 2007, the number of male full-time graduate students increased by 32 percent, compared to a 63 percent increase for female graduate students. Among part-time graduate students, the number of males increased by 10 percent and the number of females increased by 23 percent (NCES, 2009).

The percentage of American college students who are minorities has been increasing. Over thirty years ago, 15 percent of the college population was minorities, compared with 32 percent in 2007. Much of the change between the years 1976-2007 is attributed to the rising numbers of Hispanic, Asian, and Pacific Islander students. At the same time, the percentage of Asian and Pacific Islander students rose from 2 percent to 7 percent and the Hispanic percentage rose from 4 percent to 11 percent. The percentage of African American students was 9 percent at the beginning of the time period rising to 13 percent in 2007 . In the past decade, African Americans have also made advances in doctoral degrees (National Science Foundation [NSF], 2007). From 1996 to 2006, the number of African American doctoral recipients increased 27\%. The aforementioned total of African American $\mathrm{PhDs}$ is in 


\section{MInstitute Macrothink $_{\text {Int }}$}

International Journal of Education

ISSN 1948-5476

2012, Vol. 4, No. 2

comparison to the PhDs conferred by all United States universities which increased by $8 \%$. In the last twenty years, the number of African Americans who received doctorates in science and engineering have also more than doubled (Redd, 2008). As depicted in Table I:

Table 1: Total fall enrollment in degree-granting institutions, by sex of student and attendance status: Selected years, 1970 through 2007 [In thousands]

\begin{tabular}{lcrrrrrrrrrrrrrr}
\hline Sex and & \multicolumn{1}{c}{ Institutions of higher education } & \multicolumn{1}{c}{ Degree-granting institutions } \\
attendance status & 1970 & 1975 & 1980 & 1985 & 1990 & 1995 & 2000 & 2001 & 2002 & 2003 & 2004 & 2005 & 2006 & 2007 \\
Total & $\mathbf{8 , 5 8 1}$ & $\mathbf{1 1 , 1 8 5}$ & $\mathbf{1 2 , 0 9 7}$ & $\mathbf{1 2 , 2 4 7}$ & $\mathbf{1 3 , 8 1 9}$ & $\mathbf{1 4 , 2 6 2}$ & $\mathbf{1 5 , 3 1 2}$ & $\mathbf{1 5 , 9 2 8}$ & $\mathbf{1 6 , 6 1 2}$ & $\mathbf{1 6 , 9 1 1}$ & $\mathbf{1 7 , 2 7 2}$ & $\mathbf{1 7 , 4 8 7}$ & $\mathbf{1 7 , 7 5 9}$ & $\mathbf{1 8 , 2 4 8}$ \\
\hline Sex & & & & & & & & & & & & & \\
Males & 5,044 & 6,149 & 5,874 & 5,818 & 6,284 & 6,343 & 6,722 & 6,961 & 7,202 & 7,260 & 7,387 & 7,456 & 7,575 & 7,816 \\
Females & 3,537 & 5,036 & 6,223 & 6,429 & 7,535 & 7,919 & 8,591 & 8,967 & 9,410 & 9,651 & 9,885 & 10,032 & 10,184 & 10,432 \\
\hline & & & & & & Attendance status & & & & & & & \\
Full-time & 5,816 & 6,841 & 7,098 & 7,075 & 7,821 & 8,129 & 9,010 & 9,448 & 9,946 & 10,326 & 10,610 & 10,797 & 10,957 & 11,270 \\
Part-time & 2,765 & 4,344 & 4,999 & 5,172 & 5,998 & 6,133 & 6,303 & 6,480 & 6,665 & 6,585 & 6,662 & 6,690 & 6,802 & 6,978 \\
\hline
\end{tabular}

Source: U.S. Department of Education, National Center for Education Statistics (2009).

Digest of Education Statistics, 2008 (NCES 2009-020), Table 18

The enrollment of African Americans and students of color in graduate programs is one of many problems facing this country. A lack of minority graduate students in the educational pipeline means a lack of minorities in higher education and despite minimal gains recruiting, retaining, and graduating minority students in graduate programs, a problem still exists in the graduation of doctoral students. Many universities are searching for innovative strategies to increase retention and graduation of African American students. As the overall color scheme of the Flagship and Research I institutions across the nation has become more Asian and White, African American graduates and people of color are being displaced (Hale, 2006). Therefore, it is important to examine the historical significance of HBCUs.

\section{Historically Black Colleges and Universities (HBCUs)}

In 1965, in the Title III of the Higher Education Act of 1965, Congress officially Historically Black Colleges and Universities (HBCUs) as institution whose principal missions were and is the education of African Americans and were accredited and established before 1964. These educational institutions are accredited by a nationally recognized accrediting agency (these institutions are accredited by regional accrediting agencies) or association, as determined by the United States' Secretary of Education to be a reliable authority as to the quality of training offered or is, according to such an agency or association, making reasonable progress toward accreditation. HBCUs were founded during an era when African American students were barred from attending traditionally White, postsecondary institutions.

The first HBCU, Cheney University in Pennsylvania, was founded in 1837. It was followed by Lincoln University, founded in 1854, and Wilberforce University in Ohio which was founded in 1856 (The United Commission of Civil Rights, 2010). Wilberforce is the oldest Black-controlled HBCU in the nation (Brown \& Richard, 2007). Today, there are 
99 HBCUs. HBCUs graduate far more than their share of African American professionals. While the 99 HBCUs represent just 3\% of the nation's institutions of higher learning, they graduate nearly one-quarter of African Americans who earn undergraduate degrees and have led the increase in the number of African American doctoral degree holders. To state it differently, HBCUs graduate $75 \%$ more of their African American students than other schools do. Specifically,

- Over half of all African American professionals are graduates of HBCUs.

- Nine of the top ten colleges that graduate the most African Americans who go on to earn $\mathrm{PhDs}$ are HBCUs.

- More than 50\% of the nation's African American public school teachers and $70 \%$ of African American dentists earned degrees at HBCUs.

- United Negro College Funds (UNCF) members Spelman College and Bennett College produce over half of the nation's African American female doctorates in all science fields

(Title III Administrators, http://www.hbcut3a.org/HBCUImportantance.aspx).

Since the Civil Rights Movement opened the doors of traditionally White colleges and universities to minority students, some policymakers have challenged the relevance of HBCUs, arguing that they serve no purpose in an integrated system of higher education. One factor fueling the increase has been affirmative action programs created by colleges and universities during the late 1960s and 1970s largely to comply with Title VI of the Civil Rights Act of 1964, which prohibits several types of discrimination in student recruitment, admissions, and financial aid (Ervin \& Davenport, 2008).

\section{Affirmative Action and Minority Enrollment in Higher Education}

This growth was aided by the Supreme Court's decision in Regents of the University of California v. Bakke (438 U.S. 265, 1978), which allowed race to be a determinant in admission decisions for graduate schools. Preferential race-based programs were developed partly in response to the demands to improve the graduation rates of minority students at Traditionally White Institutions (TWIs).

According to Jacqueline Ford-Edwards (2002), affirmative action was designed to provide access in admissions to higher education for racial and ethnic minorities and women. The institutionalization of affirmative action served to diversify higher education and thus, the societal marketplace in the United States. Reversed discrimination has been a phrased coined by many in the shadows of the affirmative action debate.

In the book, The Unfinished Agenda of Brown v. Board of Education, Chism (2004) asserts that the Supreme Court's decision was the cornerstone to an ongoing African American grassroots struggle to make America live up to its creed of equality for all of its citizenry. This milestone case overturned more than half a century of legal racial segregation in America's public schools, paving the way for the Civil Rights Movement of 
the 1950s and 1960s and ultimately the Civil Rights Act of 1964. The Civil Rights Act of 1964 greatly impacted education in general, but more importantly America's higher education system. Armed with the Act's tenets, African American students that were long denied admission into TWIs now stood ready to enter post-secondary education, equipped with federally established policies and guidelines that were intended to eliminate discrimination based on race, sex or national origin in public institutions of higher learning, public facilities in local, state and federal governments, as well as employment (Civil Rights Act, 1964).

According to Ford-Edwards (2002), prior to the American Civil War education in publicly ran institutions were outlawed for African Americans. After the Civil War, northern benevolent societies, freedman bureaus, and African American churches began opening colleges specifically to educate African Americans collectively known as HBCUs. It was not until the passage of the Civil Rights Act of 1964 that more African American students began exercising their rights and enrolling in TWIs.

To eradicate the vestiges of discrimination, many states resorted to equalizing policies termed affirmative action, which provided minorities (those not self-identified as White or Caucasian) and White women certain preferences in employment and college admissions. Affirmative action policies exist in many different forms as a result of constant legal attacks by those who argue that they amounted to reverse discrimination against White males (Connor, 1985).

Consequently, affirmative action in America has experienced a downward spiral. Over the last forty years, a number of court cases, legislative mandates, and Executive Orders have sought to overturn all vestiges of educational, economic, and pursuit of liberty gains of African Americans in the United States. Supreme Court decisions during the 1970s through the 1990s significantly diluted affirmative action programs (Milakovich \& Gordon, 2001).

In 1967, in the Supreme Court Case of Bakke v. University of California (438 U.S. at 320, 1978), a White University of California at Davis medical school applicant who had been rejected for admission twice, even though he considered himself better qualified with a higher grade point average than some of the minorities who had been admitted, sued the University based on discriminatory admission policies. In the case, the Court held that "a substantial interest that legitimately may be served by a properly devised admission program involving the competitive consideration of race and ethnic origin" was permissible (In Bakke v. University of California, 438 U.S. at 320, 1978).

In writing his opinion, Justice Powell affirmed the constitutionality of affirmative action admission policies in IHE (Ervin \& Davenport, 2008). He stated that such policies not only promoted critical thinking, "processes he states are essential to the quality of higher education" (In Bakke v. University of California, 438 U.S. at 312, 1978), but they enhanced and strengthened a diverse society of contributing leaders and professionals. In 1978, Bakke argued successfully that the medical school's quota for admitting minorities amounted to reverse discrimination. The U. S. Supreme Court then agreed and Bakke was admitted to the institution (University of California Regents v. Bakke, 1978). In the Bakke decision, 
Justice Powell affirmatively addressed the use of race in a "holistic" admissions process by recognizing a constitutional aspect of educational autonomy for universities and colleges in deciding mission, purpose, and practices Gutter at 123 S.Ct. 2325. Justice Powell stated "the freedom of a university to make its own judgments as to education includes the selection of its student body" Bakke, supra, at 312.

However, in 1996, California voters passed Proposition 209. The initiative prohibited discrimination against or preferential treatment for any individual or group in public employment, education, or contracting on the basis of race, sex, color, ethnicity, or national origin (Ervin \& Davenport, 2008). Voters in Washington State followed suit in 1998, and voters in Texas accepted similar initiatives as well (Chang, Jones, \& Hakuta, 2000) Meanwhile Grutter v. Bollinger (539 U.S. 306 (2003), a case in which the United States Supreme Court upheld the affirmative action admissions policy of the University of Michigan Law School, 5-4 decision, was overturned by a referendum of Michigan voters.

On November 9, 1999, the Governor of Florida issued Executive Order 99-281 to establish the 'One Florida Initiative' which abolished the use of race as a factor in university admissions (State of Florida, 1999). Other states also began implementing these and similar measures. In 2003, the State of California denied enrollment of qualified high school seniors because of instituted enrollment caps. These and other similar actions created an even wider gap in the equality in admission of minority students and the racial/ethnic make-up and complexion of this country IHE in TWIs.

The State of Texas, in 2005 through Senate Bill 254, instituted caps on the number of entering freshmen, the total enrollment of freshmen and sophomore students, with a portion of the cap conditionally set aside for the enrollment of minority students (Jaschick, 2008) and Arizona approved Proposition 107 in November 2010. It bans "consideration of race, ethnicity, or gender by any unit of state government, including the state's public colleges and universities." (Chace, 2011)

The practice of considering race as one of many factors in admission to our nation's colleges and universities was upheld in Grutter v. Bollinger, 539 U.S. 306 (2003), where the U.S. Supreme Court affirmed the admissions policy of the University of Michigan Law School. In her opinion for the court, Justice Sandra Day O'Connor asserted that the University of Michigan Law School had a compelling interest in promoting diversity within its student body. She argued that universities are the training ground for our nation's leaders and that society as a whole has a stake in diversity on campuses: "In order to cultivate a set of leaders with legitimacy in the eyes of the citizenry, it is necessary that the path to leadership be visibly open to talented and qualified individuals of every race and ethnicity."

Finally, in Fisher v. University of Texas at Austin, the first federal litigation challenging the use of race in university admissions since the Supreme Court's 2003 decision which upheld the University of Michigan Law School's race-conscious admissions process in Grutter v. Bollinger, was filed by two white students who were denied entry into UT Austin filed a challenge to the university's admission policies in 2008. In State of Texas, most students are admitted to UT Austin under the Top Ten Percent Plan, which 
guarantees admission to all Texas students in the top ten percent of their high school class; those not in the top percent are admitted under a holistic admissions process that considers race as one of many factors in a student's application file. In considering the aforementioned standard, the Fifth Circuit Appeals Court reasoned:

"A university may decide to pursue the goal of a diverse student body, and it may do so to the extent it ties that goal to the educational benefits that flow from diversity. The admissions procedures that UT adopted, modeled after the plan approved by the Supreme Court in Grutter, are narrowly tailored-procedures in some respects superior to the Grutter plan because the University does not keep a running tally of underrepresented minority representation during the admissions process. We are satisfied that the University's decision to reintroduce race-conscious admissions was adequately supported by the "serious, good faith consideration" required by Grutter. Finally, it is neither our role nor purpose to dance from Grutter's firm holding that diversity is an interest supporting compelling necessity. Nor are we inclined to do so. The role of black athletes in the southern universities forty years ago presents diversity's potential better than can we, although at that early juncture, it was ability overcoming a barrier of race" (Fisher at 247).

Therefore, affirmative action allows all citizens, independent of race, ethnicity, gender or socioeconomic status, to become full participants in our society. Affirmative action initiatives in the last few decades have been negatively impacted and thus disenfranchised those persons they were designed to help who are now left by the wayside. Ballot initiatives eliminated all remnants of affirmative action policies in their respective systems of higher education and state governments. However, despite their best efforts, they did not totally eliminate it. They still have affirmative action; they have just re-characterized the term and gave new names and meanings to it (Orfield \& Miller, 1998; Klink, 2003; Rivers, 2000).

Former President George Bush (1991), described the unique mission of HBCUs. "At a time when many schools barred their doors to Black Americans, these colleges offered the best, and often the only, opportunity for a higher education" (p. 6). President Bush further stated that today, most of those barriers have been brought down by the law, yet HBCUs still represent a vital component of the American higher education system. Therefore, in the year 2012, no doubt these institutions should still exist as a vital component in higher education as the role they play in eradicating the exclusion that was, and still in some instances, the modus operandi in TWIs. Their graduation rates are the prime example of the relevance of HBCUs in today's educational arena.

\section{HBCUs and African American Graduation Rates}

While IHEs made great efforts to increase enrollment and degree success for African American students, today although HBCUs represent only $4 \%$ of all colleges and universities in the U.S., they account for nearly one-quarter of the African American bachelor's degree recipients (Redd, 2000). HBCUs play an important role in expanding educational opportunities for under-represented students. In fact, HBCUs have been increasing their involvement in graduate education and since 1996 when more HBCUs have begun to offer doctoral programs. Prior to 1996, less than one-quarter of the 99 four-year public and 
private HBCUs awarded doctorates. By 2006, the percentage of HBCUs with doctoral programs grew to $32 \%$, with just under fifty percent of the four-year public historically Black institutions offering such programs. The increase in HBCUs offering doctorates and the number of graduate students attending these programs has led to rapid growth in the number of African Americans receiving PhDs and other doctoral degrees in the past five years. In fact, the percentage increases in African American doctorates from HBCUs appears to have accelerated, while the number of these awards overall has slowed as Table 2 indicates.

Table 2: Percentages of Change in Doctoral Degrees Awarded to African Americans at HBCU Compared with All U.S. Universities

\begin{tabular}{l|l|l|l}
\hline & $1996-2000$ & $2001-2006$ & $1996-2006$ \\
\hline HBCUs $^{*}$ & $35 \%$ & $36 \%$ & $82 \%$ \\
All Universities* $^{*}$ & $25 \%$ & $3 \%$ & $27 \%$ \\
\hline
\end{tabular}

*Includes awards to U.S. Citizens and permanent residents only

Source CGSNER. ORG

According to Jennifer Millman (2007), "the U.S. workforce is rapidly transforming, thanks to changing demographics, work-force dynamics, immigration flows and globalization. At the same time, the annual labor-force growth rates will slow to nearly a standstill by the year 2025" (DiversityInc Magazine, p. 23). Labor trends show that the current work force of baby boomers is aging and by the year 2030, research indicates that there will be 35 million more jobs than people to fill them (Millman, 2007).

\section{HBCUs, Jobs, and Diversity}

Diversity in the workplace has become a global concept. Employers are looking to fill positions within their organization with individuals who are prepared to deal with all aspects of the world's global market. The Internet has changed our marketplace conceptualization, how one thinks of marketplaces, and the consumers of one's products and services. Taking the once boundary driven world into a boundless environment. Corporations must be ready with a diverse workforce to meet these boundless global demands. HBCUs are major contributors in meeting this need. 


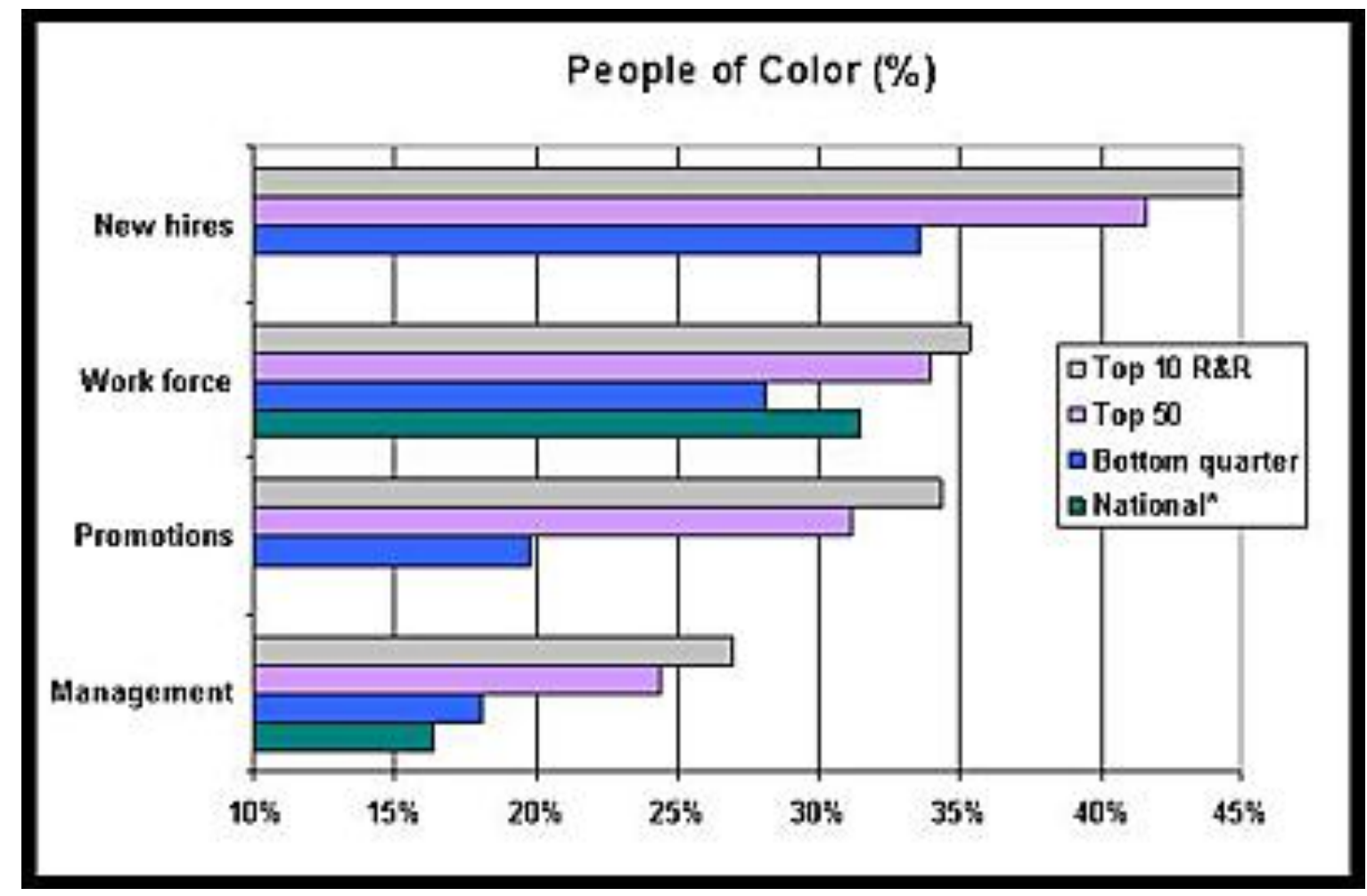

Figure 1. 2007 DiversityInc top 50 companies for diversity.

Sources: 2007 DiversityInc Top 50 Companies for Diversity survey; Equal Employment Opportunity Commission; Bureau of Labor Statistics

Diversity engenders a more creative work force, but the convergence of different attitudes, beliefs and experiences along racial/ethnic, gender, and other lines present new challenges for employers seeking to motivate their workers. According to the Bureau of Labor Statistics (2007), "the U.S. economy is expected to expand at a moderately strong pace over the coming decade, with restrained inflation, continuing strong productivity growth, and a...favorable outlook for a wide array of job opportunities" (p. 27), but most of the jobs opening up are going to be in management and business. People of color will disproportionately be the new entrants to the workforce according to DiversityInc Top Fifty Companies for Diversity (Figure 2), thus making the contributions that HBCUs make in this effort invaluable (Bureau of Labor Statistics, 2007).

As HBCUs continue to play a vital role in today's higher education landscape and workplace, the 2008 edition of "America's Best Black Colleges" marked the first time U.S. News \& World Report has released a stand-alone ranking of HBCUs. Despite the recognition, HBCUs have been hit particularly hard by the recession; therefore, it is an important time to analyze their role in educating the neediest students in the higher education landscape. As Mickey Burnim (president of Bowie State University of the University System of Maryland) (2008) stated, the challenge for HBCUs in the 21st century is how to remain true to their historic mission of providing access for African Americans while doing whatever is necessary to insure the long-term viability of the institution. 


\section{Conclusion}

The need for an educated citizenry is more important now than ever before. HBCUs are of importance in providing a diverse, educated citizenry that is seen in the following accomplishments:

1) More than 80 percent of all African Americans who received degrees in medicine and dentistry were trained at the two HBCUs of medicine and dentistry-Howard University and Meharry Medical College.

2) HBCUs have provided undergraduate training for three-fourths of all African Americans holding doctorate degrees; three-fourths of all African American officers in

3) the armed forces; and four-fifths of all African American federal judges (National Center for Educational Statistics [NCES], 1999).

4) HBCUs, in particular, Florida A\&M University, are leading institutions in awarding baccalaureate degrees to students in the life sciences, physical sciences mathematics, education, and engineering (Black Issues in Higher Education [BIHE], 2007).

5) HBCUs continue to rank high in terms of the proportion of graduates who pursue and complete graduate and professional training (Black Issues in Higher Education [BIHE], 2007).

6) Fifty percent of the African American faculty in traditionally White research universities received their bachelor's degrees at an HBCU (Hale, 2006).

HBCUs remain instrumental in creating an industrious citizenry and will be the cornerstone to globalization of the current and future marketplace.

\section{References}

Brown, M. C., \& Ricard, R. B. (2007, Fall). The honorable past and uncertain future of the nation's HBCUs. Thought and Action, 117-130.

Burnim, M. (2008) A Snapshot Look at Today's HBCU, www.aascu.org/media/public_purpose/2008/08_07burnim.pdf

Bureau of Labor Statistics. (2007). The 2007 statistical abstract. I.S. Department of Labor: Washington, D.C.

Chacem, W. (2011). Affirmative Inaction. The American Scholar. Retrieved from: http://theamericanscholar.org/affirmative-inaction/

Chang, M., Witt, D., Jones, J., \& Hakuta, K. (2000). Compelling interest: Examining the evidence on racial dynamics.

Chism, K. G. (2004). In The unfinished agenda on Brown v. Board of Education (landmarks in civil rights history). John Wiley \& Sons. 
Civil Rights Act. (1964). Pub.L. 88-352, 78 Stat. 241.

Connor, L. (1985). The impact of affirmative action on the employment practices in Pennsylvania's state system of higher education, 1974-1984. Unpublished doctoral dissertation. University of Pittsburgh.

Ervin, C. P., \& Davenport, E. K. (2008). The university as a learning community - The purpose of diversity in higher education. Included in Critiquing Academia. Thomas Whidden \& Rex Wirth (Eds). Mellen Publishing: Lewiston, New York, pp. 203-216.

Fisher v. University of Texas at Austin, 631 F. 3d 213. Court of Appeals, 5th Circuit (2011)

Florida Governor's Executive Order Regarding Diversity - \#99-281. (1999). Retrieved from: www.myflorida.com

Ford-Edwards, J. (2002). Towards a theoretical model of minority student success: Successful Black students and their perspectives on the variables that promote and retard their retention. Thesis submitted to Drexel University.

Garibaldi, A. (Ed.) (1984). Black colleges and universities: Challenges for the future. New York: Praeger.

Grutter v. Bollinger, 123 S. Ct. 2325, 234 (2003).

Klink, M. (2003). The Reestablishment of the Florida Agricultural and Mechanical University College of Law: A policy analysis of equality of educational opportunity and legal education policy making in Florida (1949-2000). Unpublished doctoral dissertation, The Florida State University).

Jaschick, S. (2008). Nebraska Bars Use of Race in Admission. Inside Higher Education. Retrieved from: http://www.insidehighered.com/news/2008/11/05/affirm

Milakovich, M., \& Gordon, G. J. (2001). Public administration in America (7 $7^{\text {th }}$ ed.). Belmont, CA: Wadsworth Group, Thompson Learning.

Millman, J. (2007). Diversity delusion. DiversityInc Magazine. Diversity Inc. http://www.diversityinc.com/content/1757/article/1780/

National Science Foundation (NSF). (2007). Doctorate Recipients from United States Universities Summary Report 2006: Survey of Earned Doctorates. Chicago, IL: National Opinion Research Center, University of Chicago.

Orfield, G., \& Miller, E. (1998). Chilling admissions: The affirmative action crisis and the search for alternatives. Diversity and legal education: Student experiences in leading law schools. Civil Rights Project, Harvard University Press.

President George Bush. (1991). Retrieved March 26, 2008, from www.albab.com/arab/docs/pal/pal10.htm.

Proposition 209 Analysis. (1996). Retrieved July 23, 2008, from http://vote96.ss.ca.gov/Vote96/html/BP/209.htm. 


\section{Macrothink}

Redd, K. (2008). Data Sources: Trends in Graduate Enrollment and Doctoral Degrees at Historically Black Colleges and Universities, 1996 to 2006. Indianapolis, IN: USA Group Foundation.

Rivers, L. O. (2000). Florida A\&M University College of Law (1949-2000). Tallahassee, FL: Florida A\&M University Press.

(NCES 2009-020), Chapter 3.

University of California Regents v. Bakke, 438 U.S. 265 (1978).

University of California Regents v. Bakke, 438 U.S. 312 (1978).

University of California Regents v. Bakke, 438 U.S. 320 (1978).

United Commission of Civil Rights (2010). The Educational Effectiveness of Historically Black Colleges and Universities: A Briefing before the United States Commission on Civil Rights Held in Washington, D.C. Retrieved from: www.usccr.gov/pubs/HBCU_webversion2.pdf

U.S. Department of Commerce Census Statistics. (2009). Washington, DC.

U.S. Department of Education, National Center for Education Statistics. (2009). Digest of Education Statistics, 2008

\section{Copyright Disclaimer}

Copyright reserved by the author(s).

This article is an open-access article distributed under the terms and conditions of the Creative Commons Attribution license (http://creativecommons.org/licenses/by/3.0/). 